\title{
(5)

\section{Kardiovaskulær sykdom og diabetes ved afrikansk eller asiatisk bakgrunn}

OVERSIKTSARTIKKEL

\section{ARILD AAMB $\varnothing$}

E-post:a.aa@nakmi.no

Nasjonalt kompetansesenter for migrasjons- og minoritetshelse (NAKMI)

Oslo universitetssykehus, Aker

Han har skrevet artikkelen.

Arild Aambø (f. 1949) er lege og tidligere spesialist i allmennmedisin. Han er seniorrådgiver og har deltatt i Helsedirektoratets faggruppe for forebygging av makrovaskulære komplikasjoner ved diabetes.

Forfatter har fylt ut ICMJE-skjemaet og oppgir ingen interessekonflikter.

\section{TOR OLE KLEMSDAL}

Preventiv kardiologi

Oslo universitetssykehus, Aker

Han har bidratt med grundige diskusjoner om temaet, utforming samt revisjon av manus, lesing og kommentering og har godkjent innsendte manusversjon.

Tor Ole Klemsdal (f. 1958) er spesialist i indremedisin og i kardiologi, overlege og seksjonsleder. Han har deltatt i Helsedirektoratets faggruppe for forebygging av makrovaskulære komplikasjoner ved diabetes, og har hatt et $20 \%$ engasjement i Helsedirektoratet for arbeid med disse og andre retningslinjer.

Forfatter har fylt ut ICMJE-skjemaet og oppgir følgende interessekonflikter: Han har mottatt forelesningshonorarer fra MSD Norge, Astra Zeneca, BMS-Squibb Norway, Novartis Norge og SanofiAventis Norge.

\section{BAKGRUNN}

Befolkningsgrupper av ulik herkomst ser ut til å ha ulik forekomst av diabetes, ulik risiko for å utvikle kardiovaskulær sykdom og ulik respons på visse medisiner som benyttes ved disse tilstandene. Vi ønsket å gå gjennom litteraturen på dette feltet.

\section{KUNNSKAPSGRUNNLAG}

Vi har søkt i flere databaser etter systematiske oversikter publisert fra og med år 2000 og supplert med artikler fra referanselister, egne litteraturarkiver samt et pyramidesøk i Helsebibliotekets database. Totalt 37 artikler ble inkludert. 
Når det gjelder diagnostisert diabetes, er forekomsten av koronar hjertesykdom og hjerneslag ulik mellom grupper av sørasiatisk, østasiatisk, afrikansk og europeisk herkomst. Hos dem med sørasiatisk herkomst antas risikoen for koronar hjertesykdom å være dobbelt så stor som hos europeere, og sykdom inntreffer 5-10 år tidligere.

Forekomsten av hjerneslag er spesielt høy personer av afrikansk herkomst. Også risikofaktorer som dyslipidemi og hypertensjon er ulikt fordelt mellom disse gruppene. Behandlingsresponsen på medikamenter som -blokkere, ACE-hemmere og ulike statiner er ulik, for eksempel kan statindosene hos asiater ofte halveres i forhold til dosen til kaukasiere, og ACE-hemmere anbefales ikke som monoterapi ved hypertensjon hos personer av afrikansk herkomst. Ulikhetene skyldes blant annet ulik genetisk disposisjon. $\beta$ blokkere, ACE-hemmere og ulike statiner er ulik, for eksempel kan statindosene hos asiater ofte halveres i forhold til dosen til kaukasiere, og ACE-hemmere anbefales ikke som monoterapi ved hypertensjon hos personer av afrikansk herkomst. Ulikhetene skyldes blant annet ulik genetisk disposisjon.

\section{FORTOLKNING}

Funnene har klinisk betydning - bedre innsikt på feltet muliggjør optimalisert tilpasning til hver enkelt pasient, med raskere måloppnåelse og redusert risiko for bivirkninger. De anbefalingene som gis i denne artikkelen, er i samsvar med og utfyller Helsedirektoratets reviderte retningslinje for behandling av diabetes.

I et kulturelt komplekst samfunn som det norske får kravet om likeverdig behandling uansett alder, kjønn og herkomst spesiell betydning, ettersom det er påvist betydelige forskjeller i både sykdomsforekomst og respons på medikamentell behandling mellom ulike folkeslag (1). I én bestemt befolkningsgruppe kan andelen som responderer positivt på et medikament være annerledes enn andelen som responderer positivt i en annen gruppe. Denne forskjellen i medikamentrespons er til en viss grad genetisk betinget (1).

Det er derfor grunn til å tro at slike særegenheter ikke bare gjør seg gjeldende for spesielle folkegrupper i deres respektive hjemlige områder og hjemland, de består også i betydelig grad hos dem som emigrerer. Dette gjelder selv om forekomsten av både diabetes og makrovaskulær sykdom i høy grad påvirkes av livsstil, levekår og andre forhold som aktualiseres ved migrasjon (2-4). Det er også kjent at ingredienser i kostholdet kan influere på virkningen av visse medikamenter (5).

Ettersom forholdet mellom diabetes, makrovaskulær sykdom, genetiske faktorer, kost og livsstil er komplekst (2), har vi i denne artikkelen valgt en pragmatisk tilnærming.

Vi ønsket å belyse hvorvidt det hos diabetespasienter av afrikansk eller asiatisk herkomst er en annen forekomst av kardiovaskulær sykdom, hypertensjon og/eller hyperlipidemi enn hos kaukasiere. Videre ønsket vi å belyse om diabetespasienter av afrikansk eller asiatisk herkomst respondere annerledes på medisiner som forebygger kardiovaskulær sykdom enn kaukasiere.

\section{Kunnskapsgrunnlag}

I forbindelse med forarbeider til Helsedirektoratets nye retningslinje for behandling av diabetes (6) og i samarbeid med Helsedirektoratets bibliotektjeneste ble det våren 
2015 gjort et litteraturs $\varnothing \mathrm{k}$. Vi ønsket å konsentrere oss om studier som var utført blant migranter til Europa, men ønsket også ta inn studier fra opprinnelseslandet eller regionen migrantene kommer fra, da vi mener dette kan bidra til økt forståelse.

Vi søkte i databasene PubMed, Ovid MEDLINE, EMBASE, Global health, Cochrane Database of Systematic Reviews, NHS Economic Evaluation Database, Other Reviews (DARE), Technology Assessment, EBSCOs Cinahl, CDSR, EED, SveMed+ etter systematiske oversikter på norsk, svensk, dansk, engelsk og tysk publisert fra og med år 2000.

For å belyse den første problemstillingen benyttet vi søkestrengen (forenklet): Diabetes mellitus AND Asia OR Africa AND Hypertension OR Myocardial infarction OR Stroke. Søket ble avsluttet 4.2.2015.

For å belyse den andre problemstillingen benyttet vi søkestrengen (forenklet): Diabetes AND Asia OR Africa AND Statin* OR Antihypertensive* OR Thiazid* OR Diuretic*. For å være sikker på å få med litteratur som var relevant for de mest aktuelle gruppene som er kommet fra Asia og Afrika til Norge, ble det i tillegg søkt spesielt på et skjønnsmessig utvalg av nasjonalgrupper fra disse områdene. Dette søket ble avsluttet 30.3.2015. Komplett søkestrategi finnes i aambøappendiks.

Vi fikk til sammen 871 treff, og etter å ha fjernet dubletter var det 787 treff. Artiklenes relevans ble først vurdert av førsteforfatter ut fra tittel og sammendrag (fig 1). 34 artikler ble lest i fulltekst. Av disse fant vi fem oversiktsartikler fra perioden 2005-15. Materialet ble videre supplert med tre nyere oversiktsartikler som først ble publisert i perioden 2015-16 (7-9).

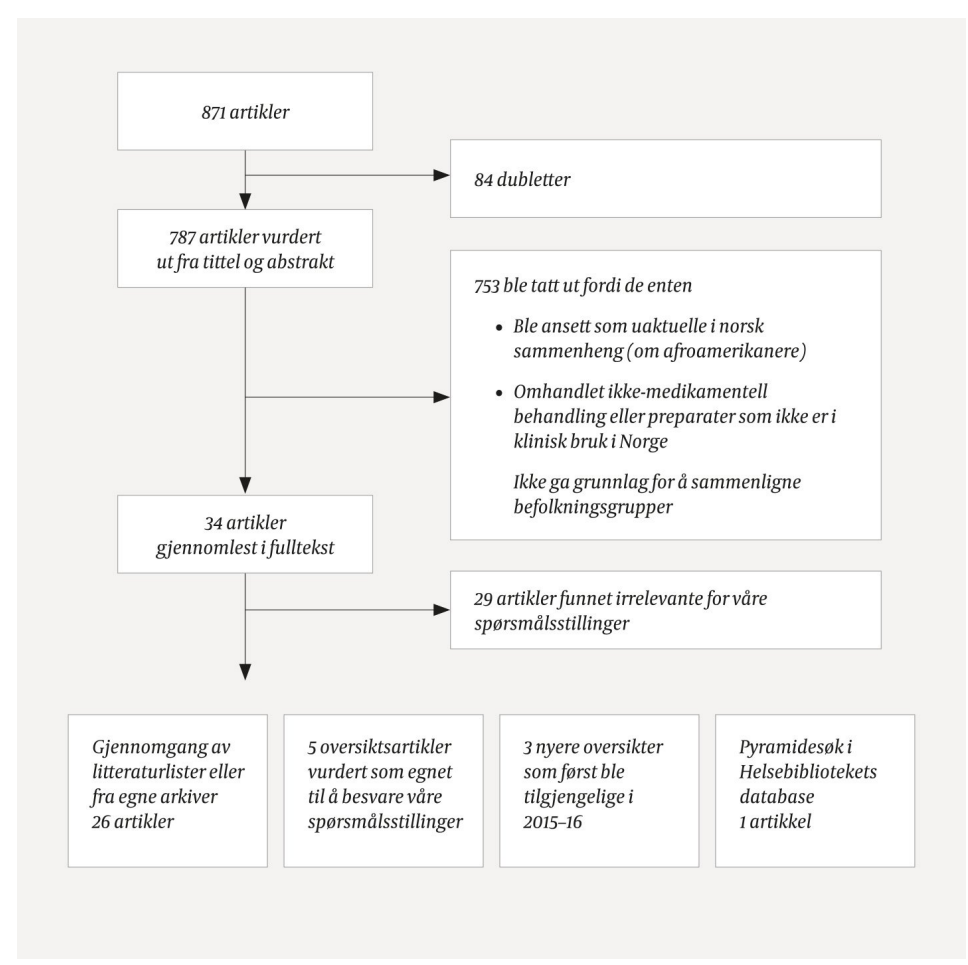

Figur 1 Resultatet av søkene etter artikler fra perioden 2000-15

Basert på funn i de utvalgte artiklene ble det dessuten i mars 2015 utført tre pyramides $ø \mathrm{k}$ i Helsebibliotekets database, på henholdsvis "hypertension AND pharmacogenomics», «825T AND hypertension» og «CYP2C19 AND Asian OR African». Fra disse søkene ble én artikkel inkludert (10). Ytterligere 26 artikler ble inkludert ved gjennomgang av de utvalgte artiklenes litteraturlister samt ved gjennomgang av artikler fra våre egne arkiver (11-38).

Vi bruker i denne artikkelen «herkomst» både om befolkningen i opprinnelseslandet, om migranter fra dette området og om deres etterkommere.

\section{Forekomst}

Det er betydelig variasjonen mellom ulike folkeslag når det gjelder forekomsten av diabetes 
og kardiovaskulære lidelser $(11,12)$, og denne variasjonen gjenspeiles host innvandrere fra de respektive regioner. Selv om vi ønsket å undersøke risikoen for kardiovaskulær sykdom ved diabetes i ulike befolkningsgrupper, er det i praksis vanskelig å skille klart mellom risiko for diabetes, risiko for kardiovaskulær sykdom og risiko for begge, da flere risikofaktorer er felles og dette ofte handler om utvikling over tid.

De omtalte etniske gruppene har for eksempel oftere insulinresistens, noe som disponerer for utvikling av både diabetes og hjerte- og karsykdom og ikke nødvendigvis via diabetes $(39,40)$. I vårt kunnskapsgrunnlag opererer man heller ikke med slike klare skiller.

Sannsynligheten for å utvikle koronar hjertesykdom er anslått til å være 1,5 ganger så høy hos personer av sørasiatisk herkomst som hos europeere og fem ganger så stor som hos kinesere. Sykdommen inntreffer dessuten i gjennomsnitt 5-10 år tidligere $(7,13,14,41)$. Hos sørasiater er insulinresistens sannsynligvis viktigere for utvikling av diabetes enn sviktende $\beta$-cellefunksjon (15).

Gruppen frembyr dessuten en unik lipidprofil - med høye verdier for triglyserider og lipoprotein (a) kombinert med lave verdier for HDL-kolesterol. Det er også en tendens til at HDL-kolesterolpartiklene er mindre og oftere dysfunksjonelle. Videre er forekomsten av de høyst aterogene, små og tette LDL-partiklene økt, selv om det totale LDL-nivået er på nivå med nivået i andre befolkningsgrupper $(8,9,16)$. Det ser dessuten ut som om hyperglykemi har større påvirkning på venstre ventrikkels funksjon hos sørasiater enn hos kaukasiere, hvilket ofte gir seg utslag i tretthet og nedsatt arbeidskapasitet $(17,18)$.

Hos innvandrere til Europa av afrikansk herkomst forekommer hypertensjon inntil 3-4 ganger så ofte som i befolkningen generelt $(19,42)$. Tilstanden er oftere karakterisert av et lavt reninnivå, og hypertensjon opptrer i yngre alder, blodtrykksstigningen er høyere og det nattlige blodtrykksfallet er mindre. Dette gir økt risiko for hjerneslag, venstre ventrikkel-hypertrofi og nyreskade (42). Lipidprofilen synes imidlertid å være gunstig i denne gruppen, de har høyere HDL-kolesterolnivå og lavere nivå av triglyserider og totalkolesterol enn befolkningen generelt (42).

\section{Respons på forebyggende medikamenter}

\section{ANTIHYPERTENSIVER}

Hos diabetespasienter av østasiaisk herkomst ser det ut til at betablokkere (propranolol) reduserer blodtrykk og hjertefrekvens mer effektivt enn hos kaukasiere. De responderer på lavere dose, men omdanner og utskiller medisinen raskere $(1,24)$.

En metaanalyse om effekten av antihypertensiv monoterapi hos diabetespasienter av afrikansk herkomst (20) viser at:

- $\beta$-blokkere gir minimal reduksjon av systolisk blodtrykk, ikke sikkert forskjellig fra placebo

- kalsiumblokkere og tiazider gir begge effektiv blodtrykkssenkning

- ACE-hemmere har liten effekt på diastolisk blodtrykk, men ser ut til å redusere risikoen for nyreskade

ACE-hemmere reduserte blodtrykket mindre hos personer av afrikansk herkomst enn hos kaukasiere - den gjennomsnittlige forskjellen var 4,6 mm Hg i systolisk og 2,8 mm Hg i diastolisk (21). ACE-hemmere bør derfor ikke være førstevalg ved ukomplisert, mild eller moderat hypertensjon i denne gruppen $(21,24)$.

Slike funn peker mot en genetisk disposisjon. Forekomsten av en genvariant, GNB3 $\mathrm{C}_{25} \mathrm{~T}$ (22), varierer da også sterkt mellom ulike nasjonaliteter og folkegrupper: I Ghana er den $91 \%$, i Kenya $89 \%$, hos østasiater $50 \%$ og hos tyskere og spanjoler $30 \%$ (23). Den kliniske 
betydningen av dette er imidlertid fortsatt uklar (10).

$\emptyset$ stasiater har om lag tredoblet risiko for hoste ved bruk av ACE-hemmer (24). Individer av afrikansk opprinnelse har tredoblet risiko for å utvikle angioødem ved bruk av ACE-

hemmer og betydelig større tilbøyelighet til å utvikle depresjon ved bruk av tiazider (24).

Dersom betablokkere skulle være indisert for østasiater (f.eks. ved arytmi, angina pectoris eller hjertesvikt), bør man være oppmerksom på at til tross for raskere

medikamentmetabolisme, vil enkelte betablokkere kunne gi større klinisk effekt her enn hos kaukasiere $(1,24)$.

For diabetespasienter av afrikansk herkomst anbefales ikke monoterapi ved hypertensjon, derimot en kombinasjon av kalsiumantagonist og ACE-hemmer (18, 25, 26). ACE-hemmere foretrekkes fremfor tiazider fordi de virker godt i kombinasjon med andre preparater, dessuten reduserer de risikoen for nyreskade. Om dette ikke er nok, kan det legges til et tiazid. Et fjerde medikament kan også være aktuelt (26).

\section{LIPIDSENKENDE MIDLER}

Studier av statinbruk i ulike befolkningsgrupper viser at østasiater oppnår samme respons som personer av annen herkomst på betydelig lavere doser. Hos pasienter i Japan var en dose på $5 \mathrm{mg}$ simvastatin like effektivt på LDL-kolesterolnivået som en dose på $20 \mathrm{mg}$, som brukes i vestlige land (27). Behandling med $10 \mathrm{mg}$ atorvastatin eller $10 \mathrm{mg}$ simvastatin hos asiater senket i løpet av åtte uker LDL-kolesterolnivået med henholdsvis $43 \%$ og $35 \%$, og over $80 \%$ av pasientene nådde behandlingsmålene på disse dosene (27).

Videre responderer diabetespasienter av sørasiatisk herkomst godt på både rosuvastatin og atorvastatin, og i en studie nådde 70-9o \% behandlingsmålet (her satt til $<2,6 \mathrm{mmol} / \mathrm{l}$ ) med doser på 10-20 mg (28).

Hos afroamerikanere ga rosuvastatin ( $10 \mathrm{mg}$ og $20 \mathrm{mg}$ ) betydelig større bedring i lipidprofilen enn tilsvarende doser atorvastatin (29). De ulike effektene av statiner kan skyldes ulik farmakokinetisk respons. Denne er som oftest genetisk betinget. En studie viste for eksempel at $40 \mathrm{mg}$ rosuvastatin ga 2,4 ganger så høy maksimal plasmakonsentrasjon hos kinesere, 2,o ganger så høy hos malaysiere og 1,7 hos indere som hos kaukasiere (30).

Muskelsmerter, den vanligste bivirkningen av statiner, er doseavhengig og anslått å forekomme hos 10-15\% av brukerne (31,32). Det kan se ut som at personer med asiatisk og afrikansk herkomst er spesielt utsatt (33). Det finnes en mulig relasjonen mellom Dvitaminmangel og statininduserte muskelsmerter (34). Dette er det viktig å være oppmerksom på hos enkelte innvandrergrupper hvor nivået av D-vitamin kan være svært lavt (35). Etter en behandlingspause der D-vitaminnivået normaliseres, kan behandlingen i mange tilfeller startes på nytt uten at smertene kommer tilbake $(34,36)$.

Videre kan interaksjonen mellom statiner og CYP3A4-hemmere (f.eks. kalsiumblokkere), som bl.a. anbefales ved hypertensjon hos personer av afrikansk herkomst (20), gi muskelsmerter (37).

Den kliniske betydningen av disse bivirkningene bør ikke undervurderes. Selv lette bivirkninger vil kunne føre til at pasienten slutter å ta medisinen.

Dersom det ikke foreligger makrovaskulær lidelse, er anbefalingen at sørasiater i likhet med andre med påvist diabetes får statiner (6), men generelt i lavere doser (27). Når det gjelder de preparatene hvor det for kaukasiere anbefales doser på 10-40 mg daglig, bør asiater ha 5-20 mg (27). Behandlingen bør dessuten startes før fylte 40 år, dvs. før det som er generelt anbefalt alder i Norge (6). Enkelte foreslår et behandlingsmål for LDL-kolesterolnivå på under $70 \mathrm{mg} / 100 \mathrm{ml}$, eller ca. $1,8 \mathrm{mmol} / \mathrm{l}$, for denne gruppen (38), mens man generelt anvender et behandlingsmål på $<2,5 \mathrm{mmol} / \mathrm{l}$ i primærforebygging ved diabetes (6). 


\section{Diskusjon}

Litteraturgjennomgangen viser at det er betydelige forskjeller mellom befolkningsgrupper av ulik herkomst når det gjelder forekomst av diabetiske komplikasjoner, medikamentrespons og bivirkninger. Vårt kunnskapsgrunnlag har imidlertid flere svakheter, og vi kan derfor per i dag ikke gi sterke anbefalinger basert på herkomst.

For det første er det ikke alltid klart hvilke nasjonalgrupper som er inkludert under fellesbetegnelser som «asiater» og «afrikanere» eller undergrupper som for eksempel «sørasiater» eller «østasiater». Videre er det stor variasjon innad i disse gruppene, ikke minst når det gjelder genetiske forhold. Genetisk disposisjon lar seg dessuten vanskelig skille fra levekår, livsstil og andre forhold som i stor grad aktualiseres ved migrasjon. Likeverdig behandling må derfor vurderes ut fra oppnådd virkning sett i forhold til eventuelle bivirkninger hos hver enkelt pasient (1).

Men klinikeren bør være oppmerksom på at man ved forebygging og/eller behandling av diabetespasienter av asiatisk eller afrikansk herkomst kan komme til å stå overfor flere tilfeller av «non-responders» (pasienter der medisinen ikke virker, men der bivirkninger kan oppstå selv om medikamentet ikke har god effekt) så vel som hyppigere bivirkninger, for eksempel muskelsmerter, ved bruk av statiner (33).

Det synes dessuten å være enighet om at diabetespasienter av afrikansk herkomst med hypertensjon ikke skal ha monoterapi med ACE-hemmer, men kombinasjonsbehandling med ACE-hemmer og kalsiumblokker eller ACE-hemmer og et tiazid $(25,26)$. Hos personer av sørasiatisk herkomst med diabetes bør man vurdere primærforebygging med statiner tidligere enn den generelle anbefalingen tilsier (dvs. før 40 år) og ved noe lavere verdier av LDL-kolesterol $(6,38)$.

Som generell regel sier vi «start lower, go slower», dvs. start med forholdsvis lave doser, $\varnothing \mathbf{k}$ forsiktig inntil ønsket effekt, og vær særlig oppmerksom på bivirkninger. Dersom virkningen uteblir, bør det tidlig vurderes å bytte til et annet preparat.

Avslutningsvis vil vi minne om at det hos enkelte av pasientene kan være særlige utfordringer knyttet til språk, forkunnskaper og muligens sykdomsforståelse. Det krever gode kommunikasjonsferdigheter og god tid for å sikre at pasienten forstår at forebyggende behandling ikke er en «kur», men et tiltak som krever vedvarende medisinering $(43,44)$.

\section{HOVEDBUDSKAP}

Der er betydelige forskjeller mellom personer av afrikansk, asiatisk og europeisk herkomst i forekomst av makrovaskulær sykdom ved diabetes

Hos personer av afrikansk og asiatisk herkomst bør den medikamentelle behandlingen startes opp med noe lavere doser og forsiktig økes inntil ønsket effekt

Personer av afrikansk herkomst med hypertensjon bør få kombinasjonsbehandling, enten med ACE-hemmer og kalsiumblokker eller med ACE-hemmer og et tiazid

\section{LITTERATUR:}

1. Burroughs VJ, Maxey RW, Levy RA. Racial and ethnic differences in response to medicines: towards individualized pharmaceutical treatment. J Natl Med Assoc 2002; 94:1 - 26. [PubMed]

2. Mechanick JI, Zhao S, Garvey WT. The Adipokine-Cardiovascular-Lifestyle Network: Translation to Clinical Practice. J Am Coll Cardiol 2016; 68:1785 - 803. [PubMed][CrossRef]

3. Curtis T, Kvernmo S, Bjerregaard P. Changing living conditions, life style and health. Int J

Circumpolar Health 2005; 64: 442 - 50. [PubMed][CrossRef]

4. Casali ME, Borsari L, Marchesi I et al. Lifestyle and food habits changes after migration: a focus on 
immigrant women in Modena (Italy). Ann Ig 2015; 27: 748 - 59. [PubMed]

5. Prabhakar PK, Kumar A, Doble M. Combination therapy: a new strategy to manage diabetes and its complications. Phytomedicine 2014; 21:123-30. [PubMed][CrossRef]

6. Legemidler til behandling av makrovaskulære senkomplikasjoner ved diabetes. Nasjonal faglig retningslinje for diabetes 2016. https://helsedirektoratet.no/retningslinjer/diabetes (16.10.2017).

7. Ahmed E, El-Menyar A. South Asian ethnicity and cardiovascular risk: the known, the unknown, and the paradox. Angiology 2015; 66: 405-15. [PubMed][CrossRef]

8. Bilen O, Kamal A, Virani SS. Lipoprotein abnormalities in South Asians and its association with cardiovascular disease: Current state and future directions. World J Cardiol 2016; 8: 247 - 57. [PubMed][CrossRef]

9. Bansal SK, Agarwal S, Daga MK. Conventional and advanced lipid parameters in premature coronary artery disease patients in India. J Clin Diagn Res 2015; 9: BCo7 - 11. [PubMed]

10. Guo L, Zhang LL, Zheng B et al. The C825T polymorphism of the G-protein $\beta_{3}$ subunit gene and its association with hypertension and stroke: an updated meta-analysis. PLoS One 2013; 8: e65863.

[PubMed][CrossRef]

11. Kato N. Ethnic differences in genetic predisposition to hypertension. Hypertens Res 2012;35:574 - 81. [PubMed][CrossRef]

12. Johnson JA. Ethnic differences in cardiovascular drug response: potential contribution of pharmacogenetics. Circulation 2008; 118: 1383 - 93. [PubMed][CrossRef]

13. Tziomalos K, Weerasinghe CN, Mikhailidis DP et al. Vascular risk factors in South Asians. Int J Cardiol 2008; 128: 5-16. [PubMed][CrossRef]

14. Gupta M, Singh N, Verma S. South Asians and cardiovascular risk: what clinicians should know. Circulation 2006; 113: eg24 - 9. [PubMed][CrossRef]

15. Bakker LE, Sleddering MA, Schoones JW et al. Pathogenesis of type 2 diabetes in South Asians. Eur J Endocrinol 2013; 169: R99 - 114. [PubMed][CrossRef]

16. Kulkarni KR, Markovitz JH, Nanda NC et al. Increased prevalence of smaller and denser LDL particles in Asian Indians. Arterioscler Thromb Vasc Biol 1999; 19: 2749 - 55. [PubMed][CrossRef]

17. Bathula R, Hughes AD, Panerai R et al. Indian Asians have poorer cardiovascular autonomic function than Europeans: this is due to greater hyperglycaemia and may contribute to their greater risk of heart disease. Diabetologia 2010; 53: 2120 - 8. [PubMed][CrossRef]

18. Park CM, Tillin T, March K et al. Hyperglycemia has a greater impact on left ventricle function in South Asians than in Europeans. Diabetes Care 2014; 37: 1124 - 31. [PubMed][CrossRef]

19. Schofield P, Saka O, Ashworth M. Ethnic differences in blood pressure monitoring and control in south east London. Br J Gen Pract 2011; 61:19o - 6. [PubMed][CrossRef]

20. Brewster LM, van Montfrans GA, Kleijnen J. Systematic review: antihypertensive drug therapy in black patients. Ann Intern Med 2004; 141: 614 - 27. [PubMed][CrossRef]

21. Peck RN, Smart LR, Beier R et al. Difference in blood pressure response to ACE-Inhibitor monotherapy between black and white adults with arterial hypertension: a meta-analysis of 13 clinical trials. BMC Nephrol 2013; 14: 201. [PubMed][CrossRef]

22. Dong Y, Zhu H, Sagnella GA et al. Association between the C825T polymorphism of the G protein $\beta_{3}$ subunit gene and hypertension in blacks. Hypertension 1999;34: 1193 - 6. [PubMed][CrossRef]

23. Siffert W, Forster P, Jöckel KH et al. Worldwide ethnic distribution of the G protein $\beta_{3}$ subunit $825 \mathrm{~T}$ allele and its association with obesity in Caucasian, Chinese, and Black African individuals. J Am Soc Nephrol 1999; 10: 1921 - 30. [PubMed]

24. Levy R. Medication use by ethnic and racial groups: policy implications. Journal of Pharmaceutical Health Services Research 2010; 1:15- 22.

25. Type 2 Diabetes: National Clinical Guideline for Management in Primary and Secondary Care (Update). National Collaborating Centre for Chronic Conditions (UK). London: Royal College of Physicians (UK), 2014. 
26. Egan BM, Bandyopadhyay D, Shaftman SR. Treatment of hypertension in blacks. UpToDate. https://www.uptodate.com/contents/treatment-of-hypertension-in-blacks (16.10.2017).

27. Liao JK. Safety and efficacy of statins in Asians. Am J Cardiol 2007; 99: 410 - 4. [PubMed][CrossRef]

28. Deedwania PC, Gupta M, Stein M et al. Comparison of rosuvastatin versus atorvastatin in SouthAsian patients at risk of coronary heart disease (from the IRIS Trial). Am J Cardiol 2007; 99: 1538 - 43. [PubMed][CrossRef]

29. Ferdinand KC, Clark LT, Watson KE et al. Comparison of efficacy and safety of rosuvastatin versus atorvastatin in African-American patients in a six-week trial. Am J Cardiol 20o6; 97: 229 - 35. [PubMed][CrossRef]

30. Lee E, Ryan S, Birmingham B et al. Rosuvastatin pharmacokinetics and pharmacogenetics in white and Asian subjects residing in the same environment. Clin Pharmacol Ther 2005; 78:330 - 41. [PubMed][CrossRef]

31. Harper CR, Jacobson TA. Evidence-based management of statin myopathy. Curr Atheroscler Rep 2010; 12:322 - 30. [PubMed][CrossRef]

32. Zhang H, Plutzky J, Skentzos S et al. Discontinuation of statins in routine care settings: a cohort study. Ann Intern Med 2013; 158:526 - 34. [PubMed][CrossRef]

33. Ramsey LB, Johnson SG, Caudle KE et al. The clinical pharmacogenetics implementation consortium guideline for SLCO1B1 and simvastatin-induced myopathy: 2014 update. Clin Pharmacol Ther 2014; 96: 423 - 8. [PubMed][CrossRef]

34. Gupta A, Thompson PD. The relationship of vitamin D deficiency to statin myopathy. Atherosclerosis 2011; 215: 23-9. [PubMed][CrossRef]

35. Mergenhagen K, Ott M, Heckman K et al. Low vitamin D as a risk factor for the development of myalgia in patients taking high-dose simvastatin: a retrospective review. Clin Ther 2014;36: 770 - 7 . [PubMed][CrossRef]

36. Glueck CJ, Abuchaibe C, Wang P. Symptomatic myositis-myalgia in hypercholesterolemic statintreated patients with concurrent vitamin D deficiency leading to statin intolerance may reflect a reversible interaction between vitamin D deficiency and statins on skeletal muscle. Med Hypotheses 2011; 77: 658 - 61. [PubMed][CrossRef]

37. Zhou YT, Yu LS, Zeng S et al. Pharmacokinetic drug-drug interactions between 1,4-dihydropyridine calcium channel blockers and statins: factors determining interaction strength and relevant clinical risk management. Ther Clin Risk Manag 2014; 10: 17 - 26. [PubMed]

38. Enas EA, Pazhoor HC, Kuruvila A et al. Intensive statin therapy for Indians: Part-I. Benefits. Indian Heart J 2011; 63: 211 - 27. [PubMed]

39. Stamler J, Vaccaro O, Neaton JD et al. Diabetes, other risk factors, and 12-yr cardiovascular mortality for men screened in the Multiple Risk Factor Intervention Trial. Diabetes Care 1993; 16: 434 - 44.

[PubMed][CrossRef]

40. Tandon N, Ali MK, Narayan KM. Pharmacologic prevention of microvascular and macrovascular complications in diabetes mellitus: implications of the results of recent clinical trials in type 2 diabetes. Am J Cardiovasc Drugs 2012; 12: 7 - 22. [PubMed][CrossRef]

41. Shah A, Kanaya AM. Diabetes and associated complications in the South Asian population. Curr Cardiol Rep 2014; 16: 476. [PubMed][CrossRef]

42. Agyemang C, Addo J, Bhopal R et al. Cardiovascular disease, diabetes and established risk factors among populations of sub-Saharan African descent in Europe: a literature review. Global Health 20o9; 5: 7. [PubMed][CrossRef]

43. Lee SM. A review of language and other communication barriers in health care. Washington D.C.: U.S. Department of health and human services/Office of minority health, 2003.

44. Joseph-Williams N, Elwyn G, Edwards A. Knowledge is not power for patients: a systematic review and thematic synthesis of patient-reported barriers and facilitators to shared decision making. Patient Educ Couns 2014; 94: 291 - 309. [PubMed][CrossRef] 
Publisert: 28. november 2017. Tidsskr Nor Legeforen. DOI: 10.4045/tidsskr.16.o68o

Mottatt 18.8.2016, første revisjon innsendt 27.1.2017, godkjent 16.10.2017.

(C) Tidsskrift for Den norske legeforening 2020. Lastet ned fra tidsskriftet.no 